\title{
Multiplexed profiling of secreted proteins for the detection of potential space biomarkers
}

\author{
BIRGER DIERIKS ${ }^{1 *}$, WINNOK H. DE VOS ${ }^{1 *}$, MARJAN MOREELS ${ }^{2}$, MYRIAM GHARDI $^{2,3}$, \\ RAOUL HENNEKAM $^{4}$, JOS L.V. BROERS ${ }^{5}$, SARAH BAATOUT ${ }^{1,2}$ and PATRICK VAN OOSTVELDT ${ }^{1}$ \\ ${ }^{1}$ Bioimaging and Cytometry Unit, Department of Molecular Biotechnology, Ghent University, 9000 Gent; \\ ${ }^{2}$ Laboratory Molecular and Cellular Biology, Radiobiology Unit, Belgian Nuclear Research Center, SCK•CEN, $2400 \mathrm{Mol}$; \\ ${ }^{3}$ Laboratory of Experimental Hematology and Oncology, UCL Mont-Godinne, 5530 Mont-Godinne, Belgium; \\ ${ }^{4}$ Department of Pediatrics, Academic Medical Center, University of Amsterdam, NL-1100 DD Amsterdam; \\ ${ }^{5}$ Department of Molecular Cell Biology, School for Cardiovascular Diseases (CARIM), \\ Maastricht University Medical Center, NL-6200 MD Maastricht, The Netherlands
}

Received September 6, 2010; Accepted November 24, 2010

DOI: $10.3892 / \mathrm{mmr} .2010 .405$

\begin{abstract}
Space travel exposes astronauts to a plethora of potentially detrimental conditions, such as cosmic radiation and microgravity. As both factors are hard to simulate on Earth, present knowledge remains limited. However, this knowledge is of vital importance, making space flight experiments a necessity for determining the biological effects and the underlying biochemical processes, especially when keeping future long-term interplanetary missions in mind. Instead of estimating the long-term effects, which usually implicate severe endpoints (e.g., cancer) and which are often difficult to attribute, research has shifted to finding representative biomarkers for rapid and sensitive detection of individual radiosensitivity. In this context, an appealing set of candidate markers is the group of secreted proteins, as they exert an intercellular signaling function and are easy to assess. We screened a subset of secreted proteins in cells exposed to space travel by means of multiplex bead array analysis. To determine the cell-specific signatures of the secreted molecules, we compared the conditioned medium of normal fibroblast cells to fibroblasts isolated from a patient with Hutchinson-Gilford Progeria syndrome, which are known to have a perturbed nuclear architecture and DNA damage response. Out of the 88 molecules screened, 20 showed a significant level increase or decrease, with a differential response to space conditions between the two cell types. Among the molecules that were
\end{abstract}

Correspondence to: Dr Patrick van Oostveldt, Bioimaging and Cytometry Unit, Department of Molecular Biotechnology, Ghent University, Coupure Links 653, 9000 Gent, Belgium

E-mail: patrick.vanoostveldt@ugent.be

${ }^{*}$ Contributed equally

Key words: cytokines, biomarker, space, radiation, microgravity retained, which may prove to be valuable biomarkers, are apolipoprotein C-III, plasminogen activator inhibitor type 1, $\beta$-2-microglobulin, ferritin, MMP-3, TIMP-1 and VEGF.

\section{Introduction}

Current knowledge about the environmental threats inherent in space travel remains limited. They are, however, ample and different from those on Earth: the altered gravity conditions and the presence of cosmic radiation, in particular highenergy ionizing (HZE) particles, are the most prevalent, and their biological effects are not well characterized. Although it is important to estimate the actual radiation dose, it is difficult to infer the biological impact on human individuals. Moreover, it is not known how the space environment, and in particular microgravity, contributes to the individual response. Among the known health effects for astronauts are space motion sickness, skin drying, bone loss, muscle atrophy, a decreased immune system function and increased cancer risk $(1,2)$. However, these symptoms are very general and little or no information is available on the molecular-mechanistic basis or causality in pathological conditions, such as cancer. Obtaining insight into these pathways is of crucial importance for estimating the severity of exposure to a space environment and individual radiosensitivity. This requires identification of new biological markers, which play a significant role in reducing radiation risk uncertainties and may be used in the development of rapid biological tests for prognostic (astronaut selection) or therapeutic (countermeasures) ends (3). In addition, this search for robust biomarkers has direct applications on Earth as well; for instance, by allowing the improved identification of radiosensitive patients and individualized radiotherapeutical treatment.

Current uncertainties in radiation risk estimates for deep space missions vary by a factor of 4 to $15(4,5)$. Despite the large differences, it is clear that these uncertainties are too high for manned interplanetary missions, such as Mars exploration. Moreover, most information is the result of extrapolating 
epidemiological studies performed on Earth or studies using animal models. However, the space environment is complex and to date impossible to simulate on Earth, making it difficult to estimate the actual hazard. Therefore, space experiments are the only option for accurate biodosimetry. We performed an in vitro experiment onboard the Foton spacecraft during the Foton-M3 mission to identify novel biomarkers present in extracellular fluid. Normal dermal fibroblasts (HDF) were compared to fibroblasts isolated from a patient suffering from Hutchinson-Gilford Progeria syndrome (HGPS). In this premature aging disease, a single point mutation in the LMNA gene (G608G) activates a cryptic splice site, giving rise to the production of a toxic prelamin A isoform, called progerin (6). Progerin accumulation compromises the structural integrity of the nucleus, resulting in greater susceptibility to physical stress, as well as disruption of the connection between the cytoskeleton and the nuclear lamina (7). In addition, HGPS cells display a perturbed DNA damage response, characterized by hypersensitivity, persistent activation of checkpoints and defective DNA repair (8). Since both nuclear structure and integrity are challenged in a space environment, the latter cells are expected to be more susceptible to space-induced changes in cellular responses.

Using a multiplex bead array assay, we monitored the abundance of 88 soluble proteins in the conditioned medium of both HDF and HGPS in space samples and ground controls. These proteins included chemokines, signaling molecules such as interleukins, which are up-regulated during inflammation and tumor formation (9), and also hormones involved in diverse metabolic pathways and blood proteins associated with cardiovascular effects.

\section{Materials and methods}

Foton-M3 mission. The Foton capsule is a robotic and retrievable capsule that is temperature-controlled at atmospheric pressure and used to carry scientific experiments into low Earth orbit. The Foton-M3 mission was launched on September 14, 2007 from the Baikonur Cosmodrome in Kazakhstan with a Soyuz-U rocket launcher and carried a European payload of $400 \mathrm{~kg}$. Following the launch phase, Foton-M3 was inserted into a near circular orbit around the Earth, inclined at $63^{\circ}$, with maximum and minimum altitudes of around 305 and 260 $\mathrm{km}$, respectively. During its 12-day stay in space, Foton-M3 completed a total of 190 orbits around the Earth, each orbit lasting approximately $90 \mathrm{~min}$.

Cell culture and experimental timeline, Modules and Biobox container. Passage-matched normal HDFs derived from foreskin (Promocell) and HGPS fibroblasts were grown in advanced DMEM (Invitrogen) supplemented with 2\% FCS (Invitrogen), 1\% L-glutamine, streptomycin-penicillin (Invitrogen) and $0.4 \%$ fungizone (Invitrogen) at $37^{\circ} \mathrm{C}$ in a humidified atmosphere containing $5 \% \mathrm{CO}_{2}$. The Foton-M3 mission was equipped with a temperature-regulated container, Biobox, bearing an internal centrifuge set to rotate at $1 \mathrm{~g}$ (artificial gravity). This way, the effects of microgravity $(\mu \mathrm{g})$ and cosmic radiation could be discriminated. Cells were grown to a confluency degree of $70 \%$ on Aclar $^{\circledR}$ slides, which were mounted into compact modules $120 \mathrm{~h}$ before launch
(T0-5 days) as previously described (10). Ground controls were subjected to the identical temperature conditions and gas exchange limitations as the space samples, and received similar medium exchange and fixation operations. Samples were either placed in the centrifuge (simulated gravity, $1 \mathrm{~g}$ space controls) or in static positions ( $\mu \mathrm{g}$ space samples). The Biobox incubator was sealed with the temperature stabilized at $25^{\circ} \mathrm{C}$, and transported to the Baikonur Cosmodrome. Three days before launch (T0-3 days) the Biobox incubator was integrated in the Foton-M3 capsule at the Baikonur Cosmodrome in Kazakhstan. Nine minutes and $4 \mathrm{sec}$ after launch, the centrifuge - which contained half the samples and heating were activated, thereby raising the temperature (at $5^{\circ} \mathrm{C}$ per h) until reaching the pre-defined temperature of $36.5^{\circ} \mathrm{C}$. Twenty-four hours after launch $(\mathrm{T} 0+1$ day), medium was replaced with complete growth medium by activation of a plunger. One hundred and twenty hours after launch (T0+5 days), a second plunger was fired, resulting in fixation of the cells with $0.5 \%$ paraformaldehyde. After 6 days (T0+6 days), all Biobox experiments were terminated and the temperature was lowered in order to preserve the biological material. Upon the return of Foton-M3 to Earth (T0+12 days), samples were immediately transferred to an environment of $4^{\circ} \mathrm{C}$. Both space and ground control modules were opened, and the medium was retrieved and stored at $-80^{\circ} \mathrm{C}$ for multiplex analysis.

Multiplex bead array assay. The supernatant of the two cell types was screened for the presence of 88 soluble proteins using a Multiplex array (Millipore). The 88 measured proteins are listed in Table I. The Multiplex array assay was performed according to the manufacturer's instructions. The medium samples, which were stored at $-80^{\circ} \mathrm{C}$, were defrosted only once, vortexed and centrifuged for $5 \mathrm{~min}$ for clarification, and then $25 \mu \mathrm{l}$ was removed for analysis into a master microtiter plate as described previously (11). The resulting data stream was interpreted using data analysis software developed by Applied Cytometry Systems. For each multiplex, both calibrators and controls were included on each microtiter plate. Eight-point calibrators were run in the first and last column of each plate, and three-level controls were included in duplicates.

\section{Results}

The medium of HDF and HGPS cells was screened for 88 macromolecules that are involved in various inflammatory as well as anti-inflammatory processes (Table II). Soluble protein levels were expressed in terms of log ratios - either microgravity/ground $(\mu \mathrm{g} / \mathrm{G})$, simulated gravity/ground $(1 \mathrm{~g} / \mathrm{G})$ or microgravity/simulated gravity $(\mu \mathrm{g} / 1 \mathrm{~g})$ - after correction for the detection limit. Readings below the detection limit were set equal to the detection limit, and only readings above the detection limit in space samples were selected for comparison. This approach is a highly prudent one, resulting in an underestimation of ratios where the initial value was below the detection limit. The ratios of all molecules for which levels above the detection limit were measured are presented in a heat map in Fig. 1. Twenty of these soluble proteins were found at significantly different levels with respect to the ground samples (Table II). A 2-fold increase/ decrease in abundance level was considered significant. 
Table I. List of 88 soluble proteins analyzed using the multiplex array assay with their respective least detectable dose (LDD).

\begin{tabular}{|c|c|}
\hline Soluble protein & LDD \\
\hline$\alpha-1$ Antitrypsin & $5.28 \mathrm{E}-08 \mathrm{mg} / \mathrm{n}$ \\
\hline Adiponectin & $0.001 \mu \mathrm{g} / \mathrm{ml}$ \\
\hline$\alpha$-2-macroglobulin & $0.000304 \mathrm{mg} / \mathrm{ml}$ \\
\hline$\alpha$-Fetoprotein & $0.086 \mathrm{ng} / \mathrm{ml}$ \\
\hline Apolipoprotein A1 & $3.29 \mathrm{E}-08 \mathrm{mg} / \mathrm{ml}$ \\
\hline Apolipoprotein C-III & $0.0000135 \mu \mathrm{g} / \mathrm{n}$ \\
\hline Apolipoprotein $\mathrm{H}$ & $0.000044 \mu \mathrm{g} / \mathrm{r}$ \\
\hline$\beta$-2-microglobulin & $0.000066 \mu \mathrm{g} / \mathrm{r}$ \\
\hline Brain-derived neurotrophic factor & $0.00586 \mu \mathrm{g} / \mathrm{n}$ \\
\hline Complement 3 & $2.63 \mathrm{E}-08 \mathrm{mg} / \mathrm{n}$ \\
\hline Cancer antigen 125 & $0.844 \mathrm{U} / \mathrm{n}$ \\
\hline Cancer antigen 19-9 & $0.0492 \mathrm{U} / \mathrm{r}$ \\
\hline Calcitonin & $1.208 \mathrm{pg} / \mathrm{r}$ \\
\hline CD40 & $0.0042 \mathrm{ng} / \mathrm{r}$ \\
\hline CD40 ligand & $0.004 \mathrm{ng} / \mathrm{r}$ \\
\hline Carcinoembryonic antigen & $0.1682 \mathrm{ng} / \mathrm{n}$ \\
\hline Creatine kinase-MB & $0.084 \mathrm{ng} / \mathrm{n}$ \\
\hline $\mathrm{C}$ reactive protein & $0.00000765 \mu \mathrm{g} / \mathrm{r}$ \\
\hline EGF & $1.47 \mathrm{pg} / \mathrm{s}$ \\
\hline ENA-78 & $0.0151 \mathrm{ng} / \mathrm{r}$ \\
\hline Endothelin-1 & $1.436 \mathrm{pg} / \mathrm{r}$ \\
\hline EN-RAGE & $0.005 \mathrm{ng} / \mathrm{r}$ \\
\hline Eotaxin & $8.2 \mathrm{pg} / \mathrm{r}$ \\
\hline Erythropoietin & $33.2 \mathrm{pg} / \mathrm{r}$ \\
\hline Fatty acid binding protein & $0.598 \mathrm{ng} / \mathrm{r}$ \\
\hline Factor VII & $0.204 \mathrm{ng} / \mathrm{r}$ \\
\hline Ferritin & $0.007 \mathrm{ng} / \mathrm{n}$ \\
\hline FGF basic & $19.6 \mathrm{pg} / \mathrm{r}$ \\
\hline Fibrinogen & 4.915E-08 mg/n \\
\hline G-CSF & $1 \mathrm{pg} / \mathrm{r}$ \\
\hline Growth hormone & $0.0266 \mathrm{ng} / \mathrm{n}$ \\
\hline GM-CSF & $11.48 \mathrm{pg} / \mathrm{r}$ \\
\hline Glutathione S-transferase & $0.0808 \mathrm{ng} / \mathrm{n}$ \\
\hline Haptoglobin & $0.00000125 \mathrm{mg} / \mathrm{n}$ \\
\hline ICAM-1 & $0.63 \mathrm{ng} / \mathrm{n}$ \\
\hline IFN- $\gamma$ & $0.92 \mathrm{pg} / \mathrm{r}$ \\
\hline $\operatorname{IgA}$ & 4.175E-08 mg/r \\
\hline $\operatorname{IgE}$ & $2.8 \mathrm{ng} / \mathrm{r}$ \\
\hline IGF-1 & $0.8 \mathrm{ng} / \mathrm{n}$ \\
\hline $\operatorname{IgM}$ & 7.55E-08 mg/n \\
\hline IL-10 & $3.08 \mathrm{pg} / \mathrm{n}$ \\
\hline IL-12p40 & $0.244 \mathrm{ng} / \mathrm{n}$ \\
\hline IL-12p70 & $18.72 \mathrm{pg} / \mathrm{n}$ \\
\hline IL-13 & $11.38 \mathrm{pg} / \mathrm{n}$ \\
\hline IL-15 & $0.256 \mathrm{ng} / \mathrm{ml}$ \\
\hline IL-16 & $13.24 \mathrm{pg} / \mathrm{ml}$ \\
\hline IL-18 & $10.8 \mathrm{pg} / \mathrm{ml}$ \\
\hline IL-1 $\alpha$ & $0.0326 \mathrm{ng} / \mathrm{n}$ \\
\hline
\end{tabular}

Table I. Continued.

\begin{tabular}{|c|c|c|}
\hline \multirow{2}{*}{$\frac{\text { Soluble protein }}{\mathrm{IL}-1 \beta}$} & \multicolumn{2}{|c|}{ LDD } \\
\hline & 0.292 & $\mathrm{pg} / \mathrm{ml}$ \\
\hline IL-1ra & 3 & $\mathrm{pg} / \mathrm{ml}$ \\
\hline IL-2 & 12 & $\mathrm{pg} / \mathrm{ml}$ \\
\hline IL-3 & 0.0346 & $\mathrm{ng} / \mathrm{ml}$ \\
\hline $\mathrm{IL}-4$ & 20.8 & $\mathrm{pg} / \mathrm{ml}$ \\
\hline IL-5 & 6.5 & $\mathrm{pg} / \mathrm{ml}$ \\
\hline IL-6 & 2.44 & $\mathrm{pg} / \mathrm{ml}$ \\
\hline IL-7 & 10.68 & $\mathrm{pg} / \mathrm{ml}$ \\
\hline IL-8 & 0.702 & $\mathrm{pg} / \mathrm{ml}$ \\
\hline Insulin & 0.1718 & $\mathrm{uIU} / \mathrm{ml}$ \\
\hline Leptin & 0.0206 & $\mathrm{ng} / \mathrm{ml}$ \\
\hline Lipoprotein (a) & 0.0185 & $\mu \mathrm{g} / \mathrm{ml}$ \\
\hline Lymphotactin & 0.0756 & $\mathrm{ng} / \mathrm{ml}$ \\
\hline MCP-1 & 10.4 & $\mathrm{pg} / \mathrm{ml}$ \\
\hline MDC & 2.78 & $\mathrm{pg} / \mathrm{ml}$ \\
\hline MIP-1 $1 \alpha / \mathrm{CCL} 3$ & 2.6 & $\mathrm{pg} / \mathrm{ml}$ \\
\hline MIP-1 $\beta$ & 7.58 & $\mathrm{pg} / \mathrm{ml}$ \\
\hline MMP-2 & 30 & $\mathrm{ng} / \mathrm{ml}$ \\
\hline MMP-3 & 0.04 & $\mathrm{ng} / \mathrm{ml}$ \\
\hline MMP-9 & 7.44 & $\mathrm{ng} / \mathrm{ml}$ \\
\hline Myeloperoxidase & 1.36 & $\mathrm{ng} / \mathrm{ml}$ \\
\hline Myoglobin & 0.00525 & $\mathrm{ng} / \mathrm{ml}$ \\
\hline PAI-1 & 0.0045 & $\mathrm{ng} / \mathrm{ml}$ \\
\hline Prostatic acid phosphatase & 0.00684 & $\mathrm{ng} / \mathrm{ml}$ \\
\hline PAPP-A & 0.0074 & $\mathrm{mIU} / \mathrm{ml}$ \\
\hline Prostate specific antigen, free & 0.00466 & $\mathrm{ng} / \mathrm{ml}$ \\
\hline RANTES & 0.0002415 & $\mathrm{ng} / \mathrm{ml}$ \\
\hline Serum amyloid $\mathrm{P}$ & 0.0000115 & $\mu \mathrm{g} / \mathrm{ml}$ \\
\hline Stem cell factor & 11.12 & $\mathrm{pg} / \mathrm{ml}$ \\
\hline SGOT & 0.744 & $\mu \mathrm{g} / \mathrm{ml}$ \\
\hline SHBG & 0.00026 & $\mathrm{nmol} / 1$ \\
\hline Thyroxine binding globulin & 0.0000682 & $\mu \mathrm{g} / \mathrm{ml}$ \\
\hline Tissue factor & 0.1682 & $\mathrm{ng} / \mathrm{ml}$ \\
\hline TIMP-1 & 0.04195 & $\mathrm{ng} / \mathrm{ml}$ \\
\hline TNF RII & 0.00065 & $\mathrm{ng} / \mathrm{ml}$ \\
\hline TNF- $\alpha$ & 0.798 & $\mathrm{pg} / \mathrm{ml}$ \\
\hline TNF- $\beta$ & 9.12 & $\mathrm{pg} / \mathrm{ml}$ \\
\hline Thrombopoietin & 0.646 & $\mathrm{ng} / \mathrm{ml}$ \\
\hline Thyroid stimulating hormone & 0.0056 & $\mathrm{uIU} / \mathrm{ml}$ \\
\hline VEGF & 1.5 & $\mathrm{pg} / \mathrm{ml}$ \\
\hline
\end{tabular}

Some molecule levels were typically altered by microgravity conditions, whereas others were modified solely by cosmic radiation, and yet others experienced changes due to the combined effects. In HDF, for instance, molecules such as apolipoprotein A, EN-RAGE, RANTES, MCP and IL-8 were typically augmented under microgravity conditions, but not in the centrifuge ( $1 \mathrm{~g})$. MMP-3, VEGF, TIMP-1 and cancer 


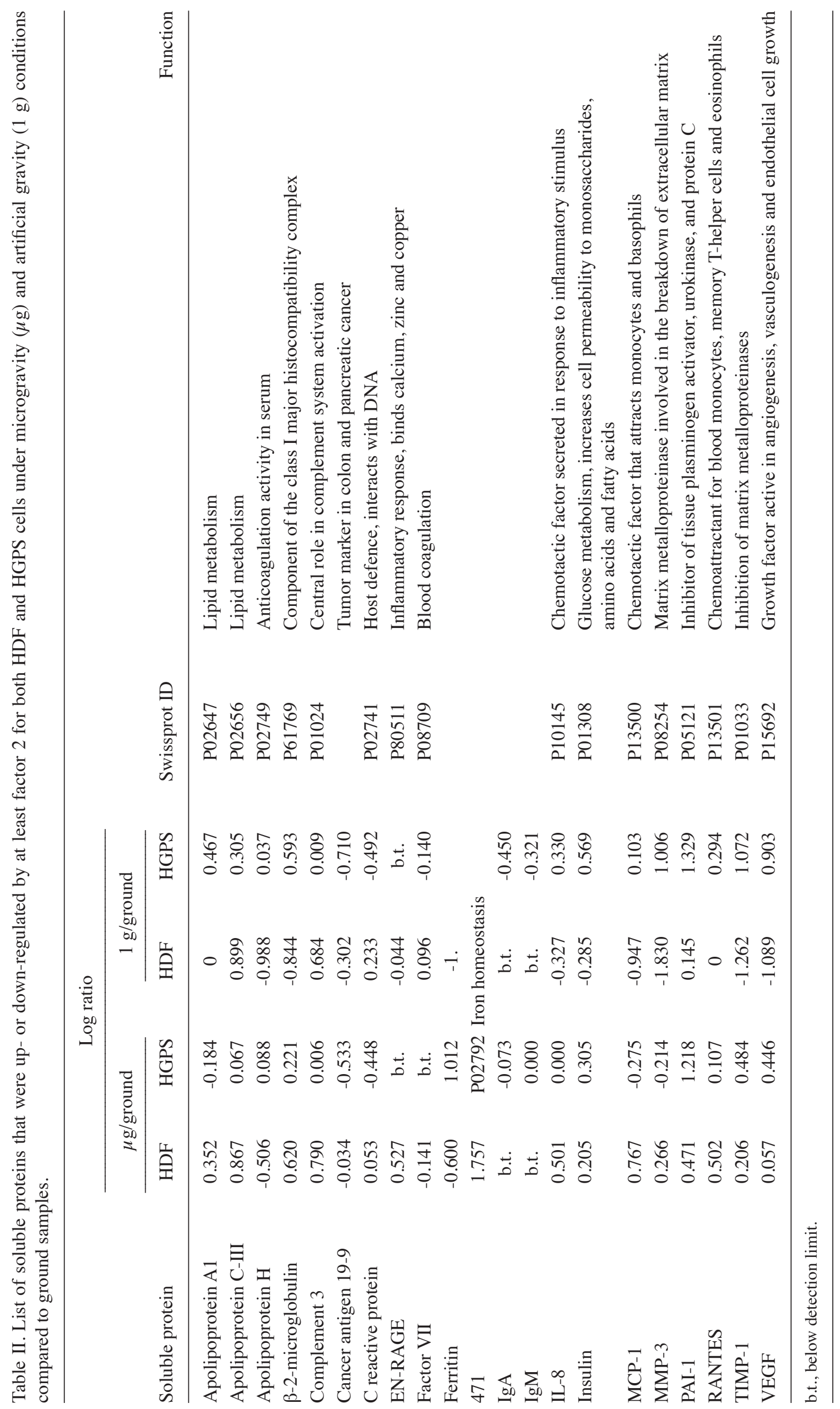




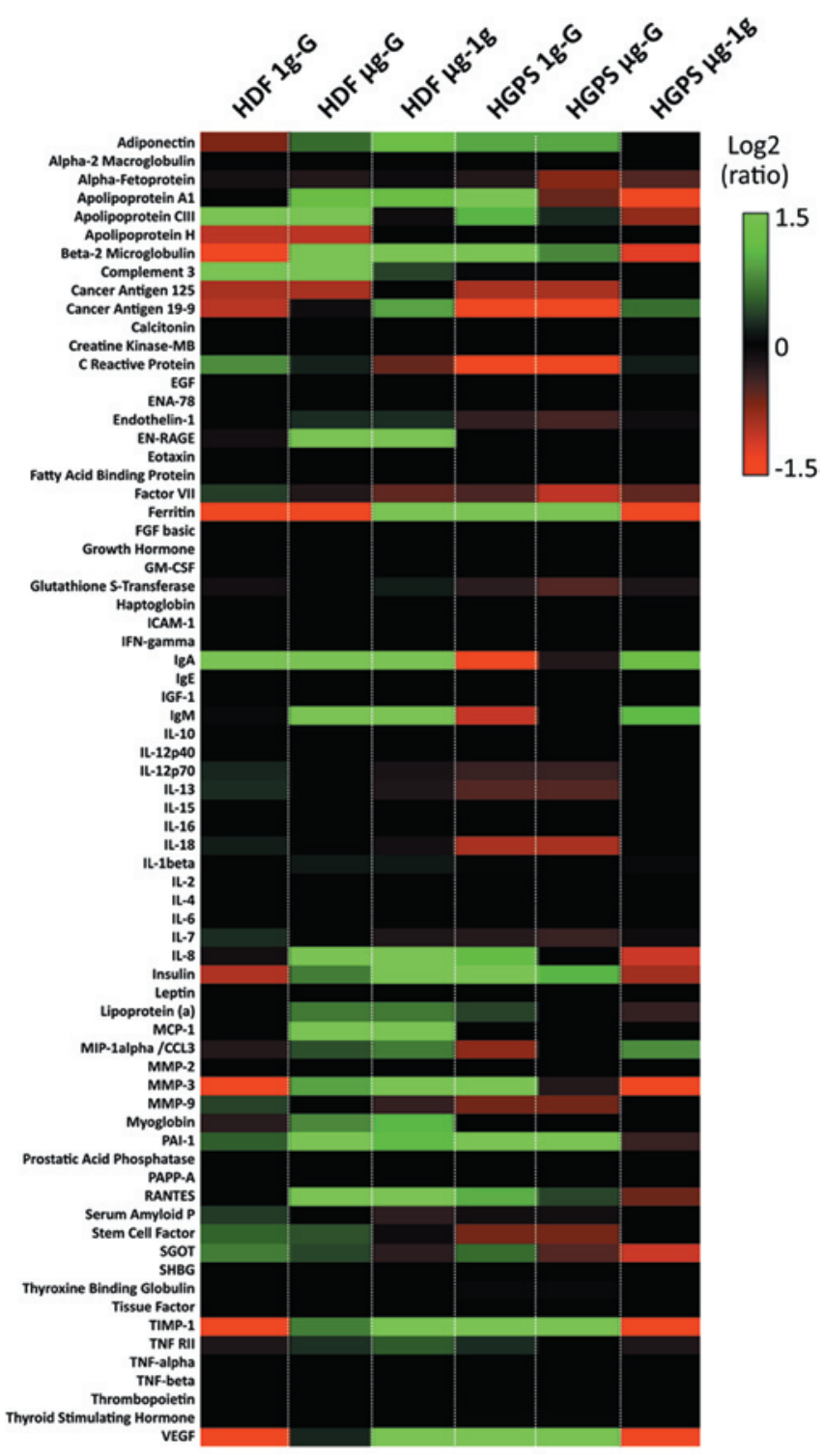

Figure 1. Heat map representing the output of secreted molecule levels measured in the medium isolated from HDF and HGPS cells and expressed as the $\log 2$ ratio after correction for detection limits. The calibration bar refers to the level of up- or down-regulation.

antigen 19-9 in turn revealed a characteristic lower abundance in space under simulated gravity (centrifuge). $\operatorname{IgA}$, ferritin, complement 3 and apolipoprotein $\mathrm{H}$ showed a similar increase/ decrease, in both the $\mu \mathrm{g}$ and $1 \mathrm{~g}$ samples, as compared to the ground controls, possibly indicating that the change in their expression may instead arise from radiation exposure and is not so dependent on the gravity conditions. Notably, similar molecules were altered in abundance in HGPS cells, although quite often in a different direction. Some molecules revealed a cell type specific response. For HDF cells, complement 3 , EN-RAGE, MCP-1 and RANTES levels were specifically altered, whereas Factor VII and C-reactive protein only changed in HGPS cells.

\section{Discussion}

This study describes the profiling of a subset of soluble molecules in human cell culture medium. To our knowledge, this is the first time that such an extensive list of soluble macromolecules has been tested for their potential use as biomarkers in space travel. Due to the limited number of flight opportunities, the use of proper controls is paramount when performing space experiments. In this experiment, we made use of two types of controls: on the one hand, ground controls underwent exactly the same conditions and experimental operations as the space samples, and on the other, half of the space samples were placed in a centrifuge that was activated at the moment the Foton-M3 capsule was placed in orbit (1 g space controls). These controls allowed us to distinguish the effects induced by microgravity.

With the presented setup, we revealed significant differences between cells exposed to space conditions and cells that remained on Earth, and demonstrated differential effects in cells under complete space conditions (microgravity) and those subjected to simulated gravity. Although it cannot be ruled out that there is some background influence from the launch conditions (vibrations and acceleration forces), internal comparisons ( $\mu \mathrm{g}-1 \mathrm{~g}$ ) clearly show that many molecules experience specific space-related effects. Certain molecules, such as apolipoprotein C-III (ApoC-III), were augmented under space conditions. Of note, high levels of ApoC-III have been correlated with an increased risk for coronary heart disease (12). The potential role of ApoC-III as a biomarker is supported by previous research (13). As many space missions indicate an increased risk of cardiovascular dysfunction, it may be opportune to further investigate the role of ApoC-III during space travel.

A strong reduction in abundance level was observed for $\beta$-2-microglobulin, ferritin, MMP-3, TIMP-1 and VEGF in the simulated gravity space samples, whereas an opposite or a much smaller change was observed in normal fibroblasts exposed to complete space conditions (microgravity and radiation). This points to the existence of a possible antagonizing or synergetic interaction between microgravity and cosmic radiation in regulating secretion, thereby causing the neutralization or more subtle fluctuations of secreted molecule levels. Additional evidence suggests that microgravity specifically affects the regulation of these proteins. For instance, EGF receptor trafficking is altered in simulated microgravity and blocks VEGF-A expression (14). The decrease of ferritin has previously been observed in plasma from astronauts returning from long-term space flights (15). Serum ferritin is frequently used as marker of iron status for medical diagnosis. Many cell types, including fibroblasts, are known to produce metalloproteinases and TIMPs in the inflammatory process $(16,17)$. In our experiments, the level of secreted MMP-3 was altered, so it is possible that cosmic radiation influences the expression level of this protein. This variation might be counterbalanced by a corresponding change of its natural inhibitors, such as TIMP1, TIMP2 and plasminogen activator inhibitor type 1 (PAI-1); an observation also made in radiation enteritis (18).

All the aforementioned proteins were detected in higher levels in simulated gravity samples of HGPS cells, in complete contrast to the HDF cells. As nuclei from HGPS cells are more rigid (19) and have a disturbed mechanotransduction (20), these cells may become less or differently responsive to the effects of microgravity. In addition, HGPS 
cells display a strongly compromised DNA damage response (8). Exactly this combination may be responsible for tilting the balance of secretion in the opposite direction. Only a few molecules, especially in HGPS cells, showed similar protein level changes in the simulated gravity and microgravity samples. This may point to effects that are solely induced by exposure to cosmic radiation, and is remotely supported by the greater radiosensitivity of HGPS cells (21). Among those molecules that were specifically related to radiation were IL- 8 and PAI-1. IL- 8 has been found to be specifically elevated in patients suffering from Glaucomatous aquous humor, acute myelogenous leukemia and myelodysplasia, underlining the potential of this marker $(22,23)$. Several lines of evidence also support the biomarker function of PAI-1. PAI-1 is known to stimulate cell migration and is involved in many processes, such as inflammation (24). Previous studies in adults with acute lung injury have reported that an early increase in the plasma levels of PAI-1 is an independent risk factor for mortality and adverse clinical outcomes (25). In addition, PAI-1 is up-regulated in the plasma of mice after exposure to radiation. Inhibition of PAI-1 by PAI-039 abolished the radiation-induced increase in the active form of plasma PAI-1, and limited the radiation-induced gene expression of other inflammatory/extracellular matrix proteins (12). In rat gastrocnemius muscle exposed to microgravity during a 2-week space flight, the transcript levels of PAI-1 were dramatically increased, while plasminogen activators remained unaltered (26).

In conclusion, this study revealed significant variations for a subset of the human secretome after space travel. Additional studies may determine the sensitivity and specificity of these signaling proteins as biomarkers for spaceflight, and in vivo assays are required to assess their validity for screening human individuals. The implementation of such a technique should focus on the measurement of secreted molecule levels in body fluids, such as blood serum $(23,27)$, urine $(28)$ or tears $(29,30)$. However, this requires careful optimization since multiplex assays generally perform well when using tissue culture supernatant samples, but may become less robust when using serum or plasma samples, especially in terms of accuracy and dynamic range $(31,32)$. Our study also shows that the composition of secretion varies significantly between cells from donors with a different genetic markup. This emphasizes the potential of the screening of individual sensitivity (e.g., for astronaut selection) or real-time monitoring. In addition, the unique combination of altered protein levels may provide discriminatory power for different types of stress inflicted onto the cells, making the use of these secreted molecule signatures an appealing alternative strategy for (space) biodosimetry.

\section{Acknowledgements}

This study was financially supported by PRODEX/ESA/ BELSPO contracts (C90-298, C90-330, C90-303, C90-380 and C90-391) and the Ghent University (BOF). The authors would like to thank the ESTEC team, especially René Demets for the excellent support, and the European Space Agency (ESA) for offering this flight opportunity. Special thanks to Pierre Coquay from Belspo for the continuous support.

\section{References}

1. Clément G: Fundamentals of Space Medicine. Kluwer Academic Publishers, Dordrecht, 2003.

2. Cucinotta FA and Durante M: Cancer risk from exposure to galactic cosmic rays: implications for space exploration by human beings. Lancet Oncol 7: 431-435, 2006.

3. Durante M: Biomarkers of space radiation risk. Radiat Res 164: 467-473, 2005.

4. Cucinotta FA, Kim MH, Willingham V and George KA: Physical and biological organ dosimetry analysis for international space station astronauts. Radiat Res 170: 127-138, 2008.

5. Setlow RB: The hazards of space travel. EMBO Rep 4: 1013-1016, 2003.

6. Verstraeten VL, Broers JL, van Steensel MA, et al: Compound heterozygosity for mutations in LMNA causes a progeria syndrome without prelamin A accumulation. Hum Mol Genet 15: 2509-2522, 2006.

7. Lee JS, Hale CM, Panorchan P, et al: Nuclear lamin A/C deficiency induces defects in cell mechanics, polarization, and migration. Biophys J 93: 2542-2552, 2007.

8. Liu Y, Rusinol A, Sinensky M, Wang Y and Zou Y: DNA damage responses in progeroid syndromes arise from defective maturation of prelamin A. J Cell Sci 119: 4644-4649, 2006.

9. Feldmann M: Many cytokines are very useful therapeutic targets in disease. J Clin Invest 118: 3533-3536, 2008.

10. Dieriks B, De Vos WH, Meesen G, et al: High content analysis of human fibroblast cell cultures after exposure to space radiation. Radiat Res 172: 423-436, 2009.

11. Dieriks B, De Vos WH, Derradji H, Baatout $S$ and Van Oostveldt P: Medium-mediated DNA repair response after ionizing radiation is correlated with the increase of specific cytokines in human fibroblasts. Mutat Res 687: 40-48, 2010.

12. Abderrahmani R, Francois A, Buard V, et al: Effects of pharmacological inhibition and genetic deficiency of plasminogen activator inhibitor-1 in radiation-induced intestinal injury. Int $\mathrm{J}$ Radiat Oncol Biol Phys 74: 942-948, 2009.

13. Morgan PE, Sturgess AD, Hennessy A and Davies MJ: Serum protein oxidation and apolipoprotein CIII levels in people with systemic Lupus erythematosus with and without nephritis. Free Radic Res 41: 1301-1312, 2007.

14. Vincent L, Avancena P, Cheng J, Rafii S and Rabbany SY: Simulated microgravity impairs leukemic cell survival through altering VEGFR-2/VEGF-A signaling pathway. Ann Biomed Eng 33: 1405-1410, 2005.

15. Smith SM, Zwart SR, Block G, Rice BL and vis-Street JE: The nutritional status of astronauts is altered after long-term space flight aboard the International Space Station. J Nutr 135: 437-443, 2005.

16. Lagente V, Manoury B, Nenan S, Le Quement C, Martin-Chouly C and Boichot E: Role of matrix metalloproteinases in the development of airway inflammation and remodeling. Braz J Med Biol Res 38: 1521-1530, 2005.

17. Tandara AA and Mustoe TA: MMP- and TIMP-secretion by human cutaneous keratinocytes and fibroblasts - impact of coculture and hydration. J Plast Reconstr Aesthet Surg: June, 2010 (E-pub ahead of print).

18. Vozenin-Brotons MC, Milliat F, Linard C, et al: Gene expression profile in human late radiation enteritis obtained by high-density cDNA array hybridization. Radiat Res 161: 299-311, 2004.

19. De Vos WH, Houben F, Hoebe RA, et al: Increased plasticity of the nuclear envelope and hypermobility of telomeres due to the loss of A-type lamins. Biochim Biophys Acta 1880: 448-458, 2010.

20. Philip JT and Dahl KN: Nuclear mechanotransduction: response of the lamina to extracellular stress with implications in aging. J Biomech 41: 3164-3170, 2008.

21. Liu B, Wang J, Chan KM, et al: Genomic instability in laminopathy-based premature aging. Nat Med 11: 780-785, 2005.

22. Kuchtey J, Rezaei KA, Jaru-Ampornpan P, Sternberg PJ and Kuchtey RW: Multiplex cytokine analysis reveals elevated concentration of interleukin-8 in Glaucomatous aqueous humor. Invest Ophthalmol Vis Sci: June, 2010 (E-pub ahead of print).

23. Kornblau SM, McCue D, Singh N, Chen W, Estrov Z and Coombes KR: Recurrent expression signatures of cytokines and chemokines are present and are independently prognostic in acute myelogenous leukemia and myelodysplasia. Blood: Aug, 2010 (E-pub ahead of print).

24. Harslund J, Nielsen OL, Brunner N and Offenberg H: Genderdependent physiological implications of combined PAI-1 and TIMP-1 gene deficiency characterized in a mouse model. Am J Physiol Regul Integr Comp Physiol 293: R1630-R1639, 2007. 
25. Sapru A, Curley MA, Brady S, Matthay MA and Flori $\mathrm{H}$ : Elevated PAI-1 is associated with poor clinical outcomes in pediatric patients with acute lung injury. Intensive Care Med 36: 157-163, 2010.

26. Naderi J, Bernreuther C, Grabinski N, et al: Plasminogen activator inhibitor type 1 up-regulation is associated with skeletal muscle atrophy and associated fibrosis. Am J Pathol 175: 763-771, 2009.

27. Njemini R, Bautmans I, Lambert M, Demanet C and Mets T: Heat shock proteins and chemokine/cytokine secretion profile in ageing and inflammation. Mech Ageing Dev 128: 450-454, 2007.

28. Stein TP and Schluter MD: Excretion of IL- 6 by astronauts during spaceflight. Am J Physiol 266: E448-E452, 1994.

29. Funk M, Schmidinger G, Maar N, et al: Angiogenic and inflammatory markers in the intraocular fluid of eyes with diabetic macular edema and influence of therapy with bevacizumab. Retina 30: 1412-1419, 2010.
30. Chong RS, Jiang YZ, Boey PY, et al: Tear cytokine profile in medicated glaucoma patients effect of monocyte chemoattractant protein 1 on early posttrabeculectomy outcome. Ophthalmology: July, 2010 (E-pub ahead of print).

31. Prabhakar U, Eirikis E, Reddy M, et al: Validation and comparative analysis of a multiplexed assay for the simultaneous quantitative measurement of Th1/Th2 cytokines in human serum and human peripheral blood mononuclear cell culture supernatants. J Immunol Methods 291: 27-38, 2004.

32. Leng SX, McElhaney JE, Walston JD, Xie D, Fedarko NS and Kuchel GA: ELISA and multiplex technologies for cytokine measurement in inflammation and aging research. J Gerontol A Biol Sci Med Sci 63: 879-884, 2008. 